\title{
Technical potential for photovoltaics on buildings in the EU-27
}

\author{
P.R. Defaix ${ }^{\mathrm{a}, 1,2}$, W.G.J.H.M. van Sark ${ }^{\mathrm{a}, *}$, E. Worrell $^{\mathrm{b}}$, E. de Visser $^{\mathrm{c}}$ \\ ${ }^{a}$ Science, Technology, and Society, Copernicus Institute, Utrecht University, Budapestlaan 6, 3584 CD Utrecht, The Netherlands \\ ${ }^{\mathrm{b}}$ Department of Innovation \& Environmental Studies, Copernicus Institute, Utrecht University, Heidelberglaan 2, 3584 CS Utrecht, The Netherlands \\ ${ }^{\mathrm{c}}$ Ecofys, Kanaalweg 16-A, 3526 KL Utrecht, The Netherlands
}

Received 16 June 2011; received in revised form 2 February 2012; accepted 2 June 2012

Available online 6 July 2012

Communicated by: Associate Editor Ursula Eicker

\begin{abstract}
Accurate knowledge on the technical potential for Building Integrated PhotoVoltaics (BIPV) in the various member states of the European Union is unavailable. To estimate the potential for BIPV we developed a method using readily available statistical data on buildings from European databases. Based on country-specific data on building characteristics and irradiation we estimate the BIPV technical potential in the EU-27 at $951 \mathrm{GWp}$. Installed it can deliver about $840 \mathrm{TWh}$ of electricity, which is equivalent to more than $22 \%$ of the expected European 2030 annual electricity demand.
\end{abstract}

(C) 2012 Elsevier Ltd. All rights reserved.

Keywords: PV potential on buildings; Photovoltaic electricity generation; BIPV

\section{Introduction}

Photovoltaics (PV) is not yet a major player in European electricity production targets for the short term (2020) but will play an increasing role for the medium (2030) and longer term (2050). To make targets realistic it is important to estimate the technical potential for PV first. It is a fairly common practice to assume an infinite potential for PV since it can also be installed on fields in large scale applications. For example the report Solar Generation V (Wolfsegger et al., 2008) states: 'Considering the vast areas of unused space (roofs, building surfaces, fallow land, deserts, etc.) the potential is almost inexhaustable'.

The recently published Solar Europe Industry Initiative (SEII) implementation plan 2010-2012 (SEII, 2010) assumes a potential of $700 \mathrm{GWp}$ installed capacity for the

\footnotetext{
* Corresponding author. Tel.: +31 30253 7611; fax: +31 302537601 . E-mail address: w.g.j.h.m.vansark@uu.nl (W.G.J.H.M. van Sark).

${ }^{1}$ Present address: Dutch Durable Solutions, Oosterlaan 63, 3971 AH Driebergen, The Netherlands.

${ }^{2}$ Tel.: +3130253 7611; fax: +31302537601.
}

EU- $27^{3}$ plus Croatia, Norway and Turkey. Another major study is the Report by the Photovoltaic Technology Research Advisory Council (PV-TRAC, 2005) which mentions a 'realistic target for 2030' of $200 \mathrm{GWp}$ installed in the EU.

An important part of the PV market however is formed by Building Integrated PV (BIPV). This segment is important for deployment of PV because of two reasons: no additional space is required because the panels are mounted on existing or newly build structures and BIPV is for a large part represented by the private consumer electricity market with a higher electricity price. PV is therefore in this segment competitive with the existing grid at an earlier

\footnotetext{
${ }^{3}$ Austria (AT), Belgium (BE), Bulgaria (BG), Cyprus (CY), Czech Republic (CZ), Denmark (DK), Estonia (EE), Finland (FI), France (FR), Germany (DE), Greece (GR), Hungary (HU), Ireland (IE), Italy (IT), Latvia (LV), Lithuania (LT), Luxembourg (LU), Malta (MT), The Netherlands (NL), Poland (PL), Portugal (PT), Romania (RO), Slovakia (SK), Slovenia (SI), Spain (ES), Sweden (SE) and the United Kingdom (UK).
} 


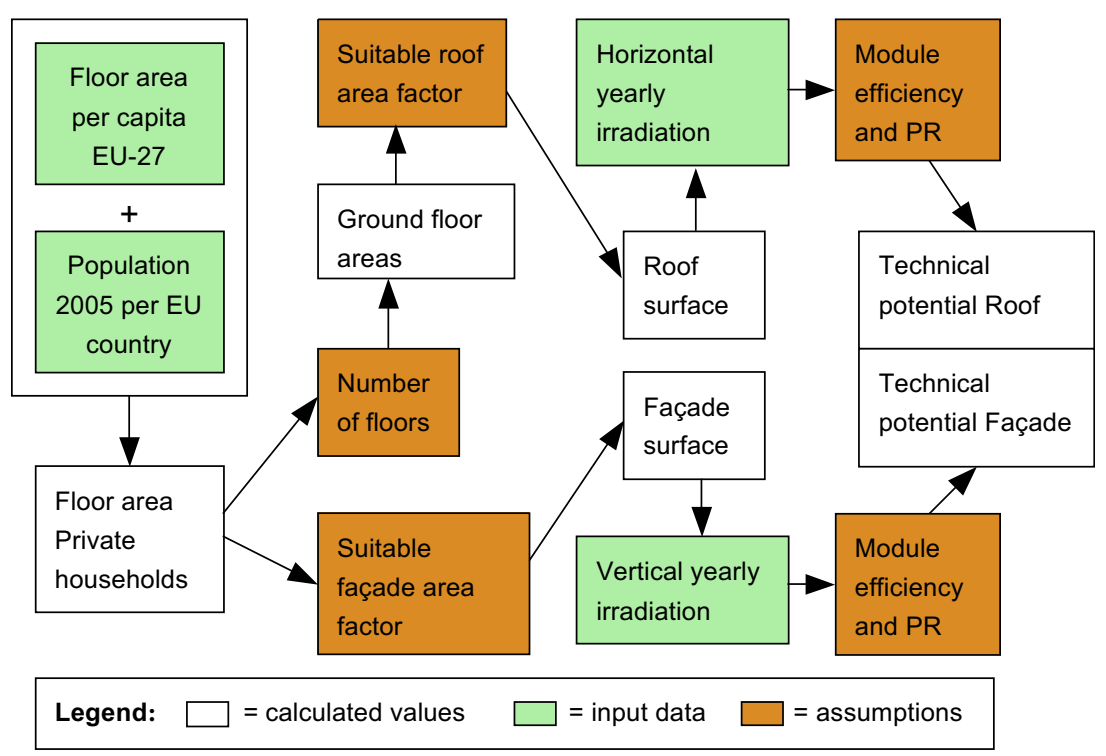

Fig. 1. Calculation scheme of the technical potential of BIPV.

stage even without subsidies. The technical potential for BIPV is however not infinite and needs to be determined.

Few studies have reported on the technical potential of PV on buildings, most refer to studies from the IEA photovoltaic power systems programme (PVPS Task7): Nowak et al. (2002) and Eiffert (2003). These two studies make use of ready to be found parameters: statistical information to estimate the available building stock combined with assumptions to correct the found surfaces for architectural suitability for solar utilisation. The authors mention in their methodology that they make use of groundfloor areas of buildings to be found in available statistics. However, trying to use a similar methodology, we could only find building stock floor areas per inhabitant in the European statistical databases (roof surfaces relate to groundfloor areas, not to floor areas).

We developed our own (refined) method to estimate the surfaces and potentials for all $27 \mathrm{EU}$ member states based on the same methodology. Our approach will help to improve and complement the estimations of earlier studies. All EU member states are included in this study instead of only nine EU countries participating in the previous PVPS programme.

Extensive research in the field of irradiation data has been performed by the Joint Research Center (JRC) of the European Commission. This has resulted in the Photovoltaic Geographic Information System (PVGIS) (Š́ri et al., 2007). Detailed irradiation data is included in relation to kilowatt-peak $(\mathrm{kWp})$ installed, but not for energy generation (i.e. $\mathrm{kWh} / \mathrm{year}$ ). The aim of this study is to connect the irradiation data with data on suitable surface areas on buildings in the EU to calculate the maximum potential for BIPV electricity generation. We estimate the potential for Europe and the year 2030. The potential depends on variables that change over time, e.g. building stock and module efficiencies. Other applications and locations of PV, e.g. field-based power plants, are beyond our scope.

\section{Methodology}

The calculation of the technical potential for BIPV starts with floor areas and population data available from public databases. From this data, the floor area is calculated and, using country-specific estimates of the number of floors, the ground floor area of the building. With the help of area factors the suitable roof and façade surfaces can then be determined. Subsequently, an irradiation database is used in combination with technical parameters for PV systems, to calculate the technical potential for BIPV electricity generation. The model structure is depicted in Fig. 1.

The steps to calculate the technical potential of BIPV for roofs and façades as depicted in Fig. 1 are explained in the following paragraphs.

\subsection{Floor area calculations}

Floor areas $\left(\mathrm{m}^{2}\right.$ per dwelling) and the average number of persons in a dwelling are derived from the Housing Statistics in the European Union 2004 (Grabmüllerova and Eriksson, 2005). Missing data for the EU $(25+2)^{4}$ are found in the Bulletin of Housing Statistics for Europe and North America 2006 (UNECE, 2006). The calculated floor area per capita is multiplied with population data (Eurostat, 2010). The step results in the floor area of private households (in $\mathrm{m}^{2}$ ) per country.

\footnotetext{
${ }^{4}$ Bulgaria and Romania became member of the EU on January 1st 2007.
} 
Table 1

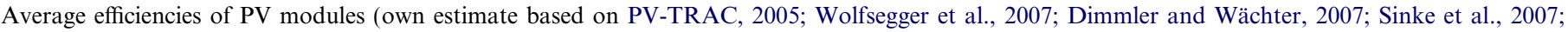
Nowak, 2006; SEII, 2010).

\begin{tabular}{|c|c|c|c|c|c|c|}
\hline & $2005(\%)$ & $2010(\%)$ & $2015(\%)$ & $2020(\%)$ & $2025(\%)$ & $2030(\%)$ \\
\hline Crystalline wafer based module & 13.1 & 16.7 & 17.7 & 19.1 & 20.5 & 22.0 \\
\hline Thin film module & 8.0 & 9.7 & 11.6 & 13.6 & 15.5 & 17.4 \\
\hline \multicolumn{7}{|l|}{ Expected technology share } \\
\hline Crystalline wafer based modules & 93.5 & 80.0 & 70.0 & 60.0 & 55.0 & 50.0 \\
\hline Thin film modules & 6.5 & 20.0 & 30.0 & 40.0 & 45.0 & 50.0 \\
\hline \multicolumn{7}{|l|}{ Weighed efficiency } \\
\hline Mix crystalline + thin film & 12.7 & 15.3 & 15.8 & 16.9 & 18.3 & 19.7 \\
\hline
\end{tabular}

\subsection{Ground floor area and roof surface calculations}

The roof area per unit of floor area depends on the number of floors of a building since higher buildings have less roof surface per dwelling than lower buildings per unit of floor area. In the Housing Statistics in the European Union 2004 (Grabmüllerova and Eriksson, 2005), the share of multi-family and high-rise dwellings in the total dwelling stock is given. Missing data can be completed by average data of the EU- $15^{5}$ or EU- $10^{6}$ because the new member (EU-10) states have a different division of the building stock. The number of floors is not available in any European statistics so the following (average) assumptions were made: Single family dwellings two floors, multi-family lowrise 3.5 floors and high-rise multi family (buildings with more than four floors) eight floors. The derived ground floor area is multiplied by a factor of 0.4 being the solar architecturally suitable area of a roof compared to the ground floor area as proposed by Nowak et al. (2002) to calculate the usable roof area for BIPV.

\subsection{Façade surface calculations}

For façade areas a different approach is followed: to determine the suitable south facing area per dwelling, using data from IEA Task 28/Annex 38 (Smeds et al., 2001) are used. The south facing areas of the standard IEA reference row house (two floors) and IEA reference apartment building (four floors) are determined in relation to their floor surface. We assume $20 \%$ of these south-facing areas to be suitable for installation of BIPV taking into account construction, historical and shading elements, and including potential vandalism (Nowak et al., 2002). Since we know the number of floors of these standard buildings we can determine the relation with the floor area instead of the ground floor area. The results for both building types were almost similar, equal to $5 \%$ of the floor area for both the

\footnotetext{
${ }^{5}$ EU from 1995 to May 1st 2004: Austria, Belgium, Denmark, Finland, France, Germany, Greece, Ireland, Italy, Luxembourg, The Netherlands, Portugal, Spain, Sweden and the United kingdom.

${ }^{6}$ On May 1st 2004, 10 countries joined the EU: eight of the formerly Communist Central and East European (CEE) countries (Czech Republic, Hungary, Poland, Slovakia, Slovenia, Latvia, Lithuania, and Estonia) plus Cyprus and Malta.
}

reference row house and apartment building $(4.9 \%$ and $4.7 \%)$.

\subsection{Technical potentials roof and façade}

To calculate the potential annual electricity production obtainable from the derived roof and façade surfaces we use formula:

$E=A \times G_{P O A} \times \eta \times P R$

In which: $E$ is the annual electricity production $(\mathrm{GWh} / \mathrm{yr})$, $A$ the usable roof or façade surface $\left(\mathrm{km}^{2}\right), G_{P O A}$ the average yearly irradiation in the tilted horizontal or vertical plane of array (POA) per square meter $\left(\mathrm{kWh} / \mathrm{m}^{2} / \mathrm{yr}\right), \eta$ the average module efficiency $(\%)$ and $P R$ is the performance ratio.

The calculated roof and façade surfaces are multiplied by annual irradiation data from the Joint Research Center (JRC) (Śriri et al., 2007). These data are specifically calculated for the built environment per country, so are not country averages. For roof areas the horizontal annual irradiation for the optimum angle (in $\mathrm{kWh} / \mathrm{m}^{2}$ ) is used, assuming that the panels are tilted with an optimal angle towards the sun (dependent on the latitude). For the façade areas, the vertical annual irradiation is available.

Since we assume an annual increase in cell efficiency we choose to make all our calculations based on the period 2005-2030 and make average calculations with expected data for the whole period. The expected cell efficiency development for the period 2005-2030 is shown in Table 1. The expected efficiency development is derived from a variety of sources: PV-TRAC (2005); Wolfsegger et al. (2007); Dimmler and Wächter (2007); Sinke et al. (2007); Nowak (2006); SEII (2010). The average cell efficiencies were multiplied with packing factors derived from Phylipsen and Alsema (1995) to estimate the expected module efficiencies for the period 2005-2030. For the period 2005-2020 these were available, and subsequently extrapolated for the period 2020-2030. There are two mainstream technologies expected for use in BIPV: crystalline silicon wafers and thin film. The efficiencies used to calculate the estimated yearly electricity production were weighed by our own assumed technology mix for crystalline/thin film modules (see Table 1).

The Performance Ratio $(P R)$ expresses the difference between performance under standard test conditions and 
the actual output of the system due to losses from a deviation from standard test conditions $\left(1000 \mathrm{~W} / \mathrm{m}^{2}\right.$, AM1.5 spectrum, module temperature $\left(25^{\circ} \mathrm{C}\right)$ ), and losses due to a sub-optimal angle, as well as cable and inverter losses. Currently, $P R$ typically equals about $75 \%$. In this analysis we used $80 \%$, since we expect that $P R$ will improve due better system reliability and monitoring. The $P R$ is expected to exceed $80 \%$ as more experience is gained with roof mounted PV systems (Westerhuis et al., 2008; Reich et al., 2012). The most recent EPIA study (SEII, 2010) also assumes a $P R$ of $80 \%$ for the period 2010-2020.

\subsection{Non-residential buildings}

For non-residential buildings (e.g. agriculture, industry, offices, education, health care, hotels, retail) we assumed that the average share of the floor area is $30 \%$ of the total building stock in European countries. Specific country data are not available. This assumption is based on data from the Energy Performance Assessment for existing non-residential buildings (Poel, 2007). The average non-residential building is assumed to have four floors. The calculation steps are made similarly to those for residential buildings.

\section{Results}

Our model yields roof and façade surfaces as well as electricity output potentials. We first show the results of the surface calculations for BIPV in the EU-27 in the year
2005 in Fig. 2 in which the horizontal axis shows depicts country codes of the EU countries:

Densely populated countries have a large building stock and thus a large potential surface for BIPV. The height of the buildings influences the ratio between the façade surface and the roof surface. A clear illustration of this can be noticed in Fig. 2. Because residential buildings in the UK are lower in height than in France the UK has a larger roof potential despite their smaller population and comparable household size. The total suitable roof and façade surface for the EU-27 is estimated at $3678 \mathrm{~km}^{2}$ for residential and $1301 \mathrm{~km}^{2}$ for non-residential buildings. The suitable roof surface represents $64 \%$ of the total surface for the residential and $54 \%$ for the non-residential sector.

The potential electricity production per country is shown in Fig. 3. Electricity production is not only dependent on available roof and façade surfaces and solar irradiation but also on module efficiency. As PV module performance improves over time, the time of implementation will affect the resulting electricity generation. The model compensates for older installed modules have a lower efficiency than the ones installed later in time, by using an average efficiency. The used efficiency has been calculated by combining the efficiencies from Table 1 with the estimated numbers of installed panels in Europe (in relation to the estimated module production) to find a weighted average efficiency for the period 2005-2030. We estimated an average PV module efficiency of $17.9 \%$. Note that the majority of the panels would be installed in the 5 years before and after 2025 (see Table 2, Section 4.4).

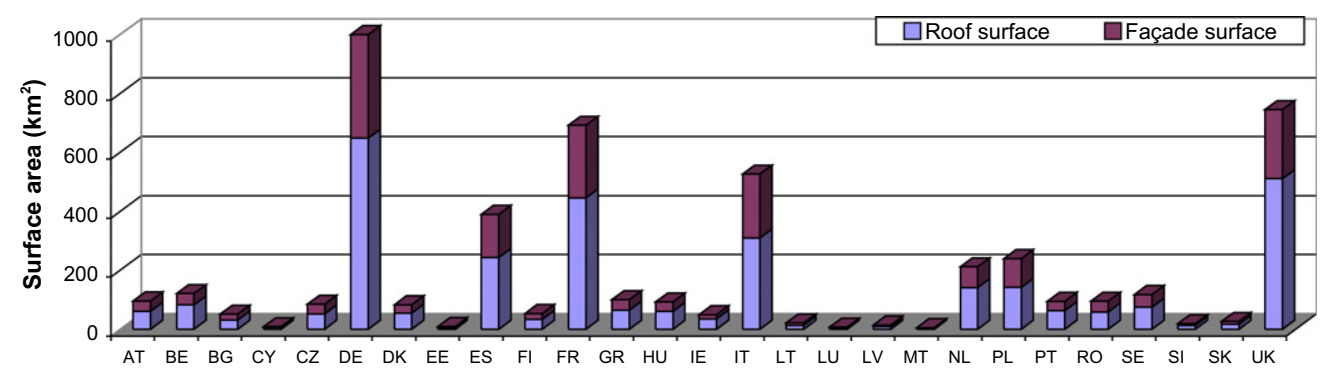

Fig. 2. Calculated usable roof and façade surfaces for BIPV in the year 2005 for all EU-27 countries.

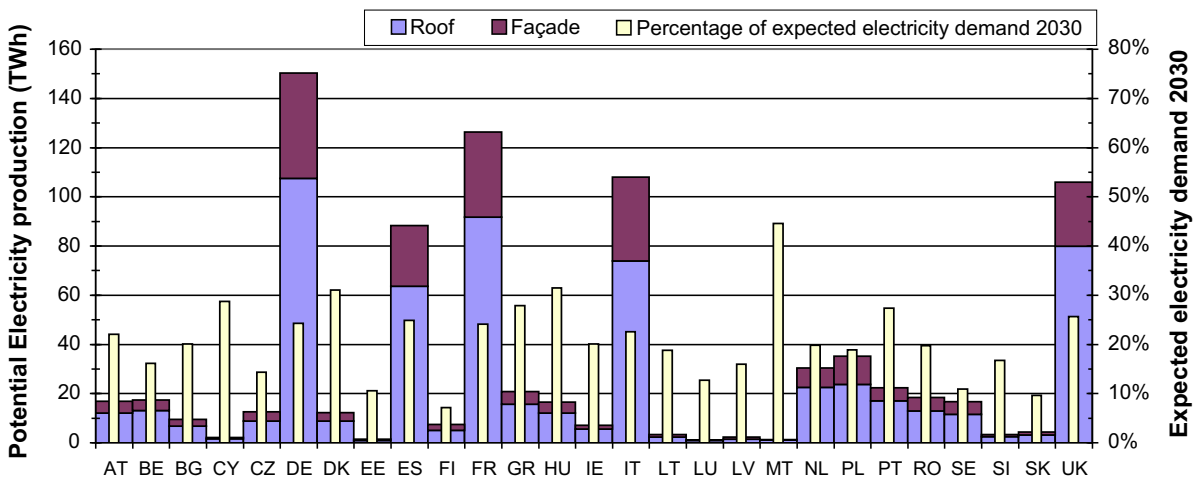

Fig. 3. Technical potential BIPV EU-27, compared to the expected annual electricity demand for the year 2030. (source: own calculations and Capros (2007)). 
Table 2

Global cumulative PV capacity scenario.

\begin{tabular}{|c|c|c|c|c|c|c|}
\hline & 2005 & 2010 & 2015 & 2020 & 2025 & 2030 \\
\hline World wide growth rate ${ }^{\mathrm{a}}, \mathrm{b}(\%)$ & 25.5 & 128 & 26.0 & 26.0 & 14.0 & 10.0 \\
\hline Annual world wide PV modules production $(\mathrm{GWp})^{\mathrm{a}}$ & 1.32 & 16.6 & 69.7 & 221 & 426 & 686 \\
\hline Assumed module production share Europe (\%) & 40.1 & 80.2 & 48.4 & 40.0 & 31.0 & 22.0 \\
\hline Estimate cumulative installed capacity world $(\mathrm{GWp})^{\mathrm{a}}$ & 5.17 & 39.1 & 270.5 & 1005 & 2673 & 5535 \\
\hline Estimate cumulative installed in Europe $(\mathrm{GWp})^{\mathrm{a}}$ & 2.07 & 29.5 & 151 & 483 & 1052 & 1775 \\
\hline
\end{tabular}

a 2005 and 2010 are actual data from EurObserver PV Barometer (2011) and EPIA Publications (2011) annual reports.

b Assumed growth rates 2011-2030 are taken from Greenpeace/EPIA solar generation VI, 2011; Teste and Masson, 2011.

Fig. 3 shows the results for the technical potential calculations for all $27 \mathrm{EU}$ countries. Germany has the highest potential in both available surface and electricity production. France and Italy produce more energy with less surface than the UK. The total potential electricity production from BIPV for the EU-27 is $840 \mathrm{TWh}$ in 2030 , which is more than $22 \%$ of the expected 2030 electricity demand in Europe (Capros, 2007). The installed capacity BIPV panels would be $951 \mathrm{GWp}$.

On the right-hand vertical axis of Fig. 3 the potential electricity production is shown relative to the final estimated annual electricity demand of that country for the year 2030 according to the Capros (2007) scenario. A small country like Malta could generate $45 \%$ of its projected annual electricity demand in 2030 with BIPV while Germany can produce $24 \%$ if they would reach the maximum potential. The lowest relative potential found according to the model is Finland with $7.1 \%$, due to the limited irradiation and relatively small building surface.

\section{Discussion}

The results are influenced by a number of assumptions made in the calculations, which are discussed below.

(1) Only existing dwellings were included, while newly built in the period until 2030 are excluded. Newly constructed buildings are likely to have increased PV opportunities if the use of solar PV is incorporated in the initial design. Also the average floor area estimates are valid for the present situation. Generally, new constructions have larger floor areas.

(2) The number of floors of buildings is unknown, this is especially important for the calculation of the available roof surface. This number of floors per building is country specific, a lot of differences exist within Europe.

(3) Statistical data to specify single family households and multi family low-rise and high-rise buildings are not available for all countries (difference in estimations is made between EU15 and EU15 + 10).

(4) We used the roof factor of 0.4 , derived from Nowak et al. (2002). It is hard to estimate how realistic this assumption is for all building types and member states. Also no distinction was made between flat roofs and tilted roofs. Panels installed on tilted roofs may not have an optimal tilt angle.

(5) The annual irradiation is an average over a time period of several years. The longer the time period the better is the estimate. The used irradiation from the JRC is calculated for urban areas per country over a period of 10 years (1981-1990). There is also a seasonal variability of the irradiation (Šruri et al., 2007), which we do not include in our analysis. However, we present only annual averages in our calculations.

(6) For the non-residential sector very limited data is available, so potential calculations are based on general data and not country specific, and can be improved.

(7) For Cyprus data was missing, and we used data from Greece to approximate the data for Cyprus and Romania only has data on the "average living room space" instead of floor area of dwellings.

We will show the sensitivity of some of the parameters in the following paragraphs.

\subsection{Assumptions on the EU-27 usable roof surfaces}

To calculate the usable roof area in the EU-27 several assumptions were made. To calculate the available floor areas heights of the buildings were needed to convert living area per habitant of a country towards roof area of the building. The influence of the estimated building heights on the available roof surface is depicted in Fig. 4.

Fig. 4 represents the sensitivity of the resulting calculated roof area to a change in the different factors. The mean values are the assumptions used in the model and represented as the $100 \%$ value on the horizontal axis. For the non-residential sector a uniform average building height has been assumed. This is a simplification since this sector is diverse as well since agricultural buildings are typical low-rise buildings and office buildings are often high rises. The fifth line in Fig. 4 represents the assumed share of non-residential in the total floor area. In reality, the share of non-residential buildings will depend on many factors, e.g. structure of the economy, building practices, and age of building stock. The only estimate found in the 


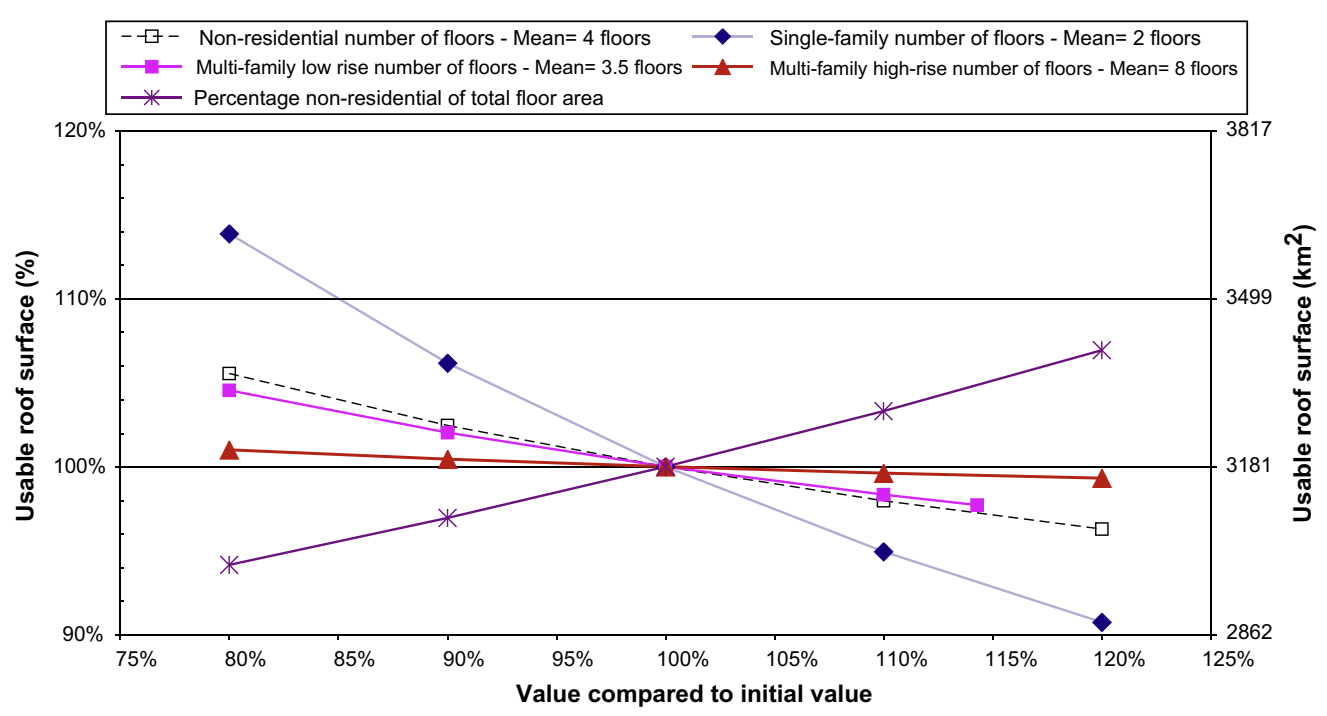

Fig. 4. Sensitivity estimated usable roof surfaces for height of buildings and non-residential number of floors.

literature (Poel, 2007) was used to make a rough estimate of the non-residential floor surface in Europe. Accurate data for most of the EU-27 countries were not available for our analysis.

\subsection{Roof area and façade area factors}

Only part of the calculated areas is suitable for installation of solar PV panels due to construction, historical and shading elements. Several factors have been used to convert the found roof and façade surfaces into usable technical electricity production potential. Fig. 5 shows the effects of the assumed usable roof area on the total BIPV potential and the assumed usable façade area and area/façade factors derived through the used IEA reference buildings.

The factor with the strongest influence on the outcome is the usable roof area factor. An increase of this parameter with $25 \%$ from 0.4 to 0.5 would give space for $759 \mathrm{GWp}$ of roof panels (up from $607 \mathrm{GWp}$ ) and an 18\% increase of the BIPV electricity generation potential from $840 \mathrm{TWh}$ to $991 \mathrm{TWh}$.

\subsection{Other factors influencing the technical potential}

The remaining factors that influence the technical potential are the performance ratio, average module efficiency and annual irradiation. The technical potential is calculated for existing roof and façade surfaces of buildings, based on population statistics of 2005. It is likely that this potential will slightly grow over the years and that the solar yield on newly built buildings will be higher due to a potentially better exposure towards the sun, if BIPV is integrated in the design and siting of the building. The latter will increase the $P R$ since the offset is included in this factor.

\subsubsection{Performance ratio}

The performance ratio is set at 0.8 . There is room for improvement as shown in Fig. 6, which is a result of

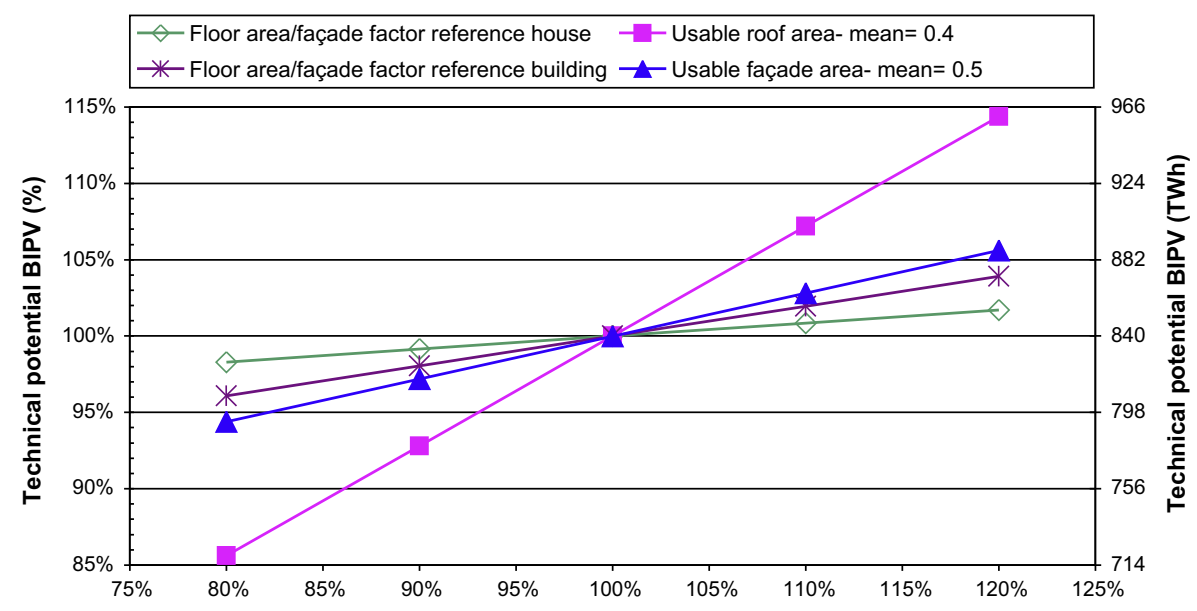

Fig. 5. Sensitivity roof and façade factors on BIPV technical potentials. 


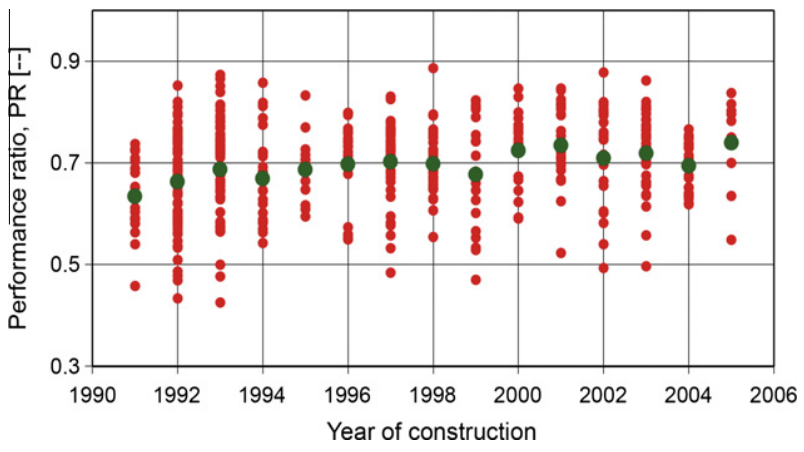

Fig. 6. Performance ratio over time. Source: Report Clavadetscher and Nordmann (2007) (reprinted with permission by the authors).

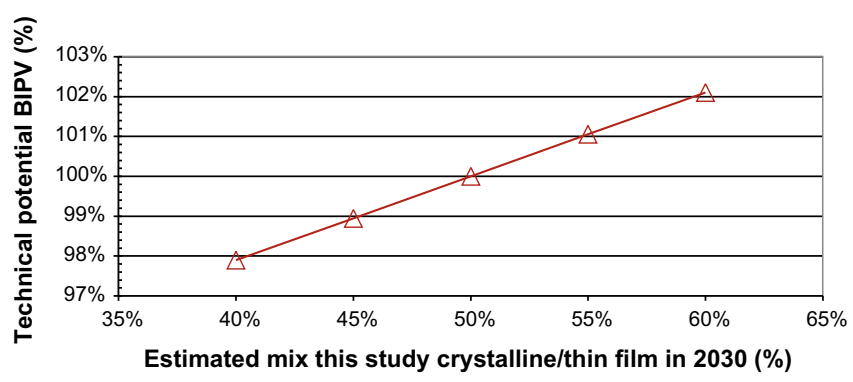

Fig. 7. Sensitivity expected ratio crystalline/thin film in 2030 .

analysing 461 grid-connected systems with a total of 1544 operational years in the IEA PVPS Task 2 Database. A gradual improvement of the average $P R$ can be seen over time from 0.64 in 1991 towards 0.74 in 2005. Although the average value is not above 0.8 , some systems have performed above 0.80 and even up to almost 0.90 in selected years.

Reliability improvement of the static inverter and other hardware components like the modules and connectors could help to improve the performance factor. De Keizer et al. (2007) concluded on the basis of a $1 \mathrm{MW}$ BIPV project in Amersfoort (The Netherlands) that remote monitoring of the $P R$ is crucial to detect hardware problems in an early stage. This should preferably be done automatically (Drews et al., 2007). Annual inspection has proven not to be adequate to maintain a high $P R$ year round. Another contributing factor is the involvement of the inhabitants in the case of BIPV. Similarly, feed-in tariffs may also lead

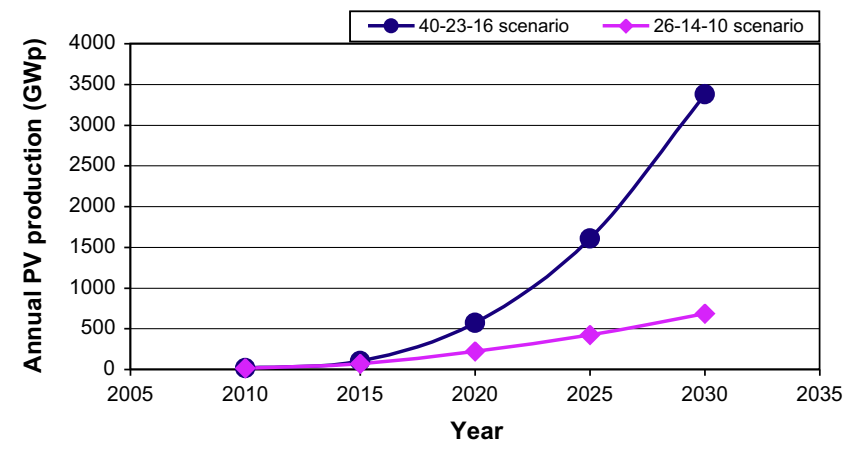

Fig. 8. Annual projected PV production 2010-2030.

to higher $P R$ values, as a loss in performance directly constitutes an economic loss.

\subsubsection{Average module efficiencies (ratio crystallinelthin film)}

Module efficiency was calculated based on current literature. At the same time the usage of thin film modules, with a lower efficiency, is likely to increase if thin film continues to compete with lower investments. In the model, a gradual shift from silicon towards thin film $(6.5 \%$ in 2005 towards $50 \%$ in 2030) has been assumed. This assumption lowers the average module efficiency, and hence decreases the technical potential. The influence of this assumption on the potentials is depicted in Fig. 7.

\subsection{Limitations to the technical potential}

BIPV power generation is also limited by the production capacity for PV modules. PV is a world market from which Europe can purchase a limited share. Table 2 shows the annual module production with growth rate estimates taken from the 2011 Greenpeace-EPIA accelerated scenario (Teske and Masson, 2011). The growth rates used are $26 \%$ for $2011-2020,14 \%$ for $2021-2025$ and $10 \%$ for 2026-2030. The installed capacities in Europe are estimated shares.

Table 3 and Fig. 8 show what would happen if the $26 \%$ growth rate would be replaced by a $40 \%$ growth rate up to 2020 (followed by $23 \%$ then $16 \%$ ) due to policy driven stimulation when grid parity in most European countries is likely to happen (Defaix, 2009). In a strong growth scenario Europe can achieve the 2030 installed capacity by

Table 3

Extended growth scenario.

\begin{tabular}{|c|c|c|c|c|c|c|}
\hline & 2005 & 2010 & 2015 & 2020 & 2025 & 2030 \\
\hline World wide growth rate ${ }^{\mathrm{a}, \mathrm{b}}(\%)$ & 25.5 & 128 & 40 & 23 & 23 & 16 \\
\hline Annual world wide PV modules production $(\mathrm{GWp})^{\mathrm{a}}$ & 1.32 & 16.6 & 106 & 571 & 1608 & 3378 \\
\hline Cumulative installed capacity world $(\mathrm{GWp})^{\mathrm{a}}$ & 5.17 & 39.1 & 342 & 1969 & 7515 & 20,346 \\
\hline Estimate cum installed Europe $(\mathrm{GWp})^{1}$ & 2.07 & 29.5 & 184 & 913 & 2792 & 6008 \\
\hline
\end{tabular}

\footnotetext{
${ }^{\text {a }} 2005$ and 2010 are actual data from EurObserver PV Barometer (2011) and EPIA Publications (2011) annual reports.
}

b Assumed growth rates 2011-2030 are taken from Teske and Masson, 2011. 


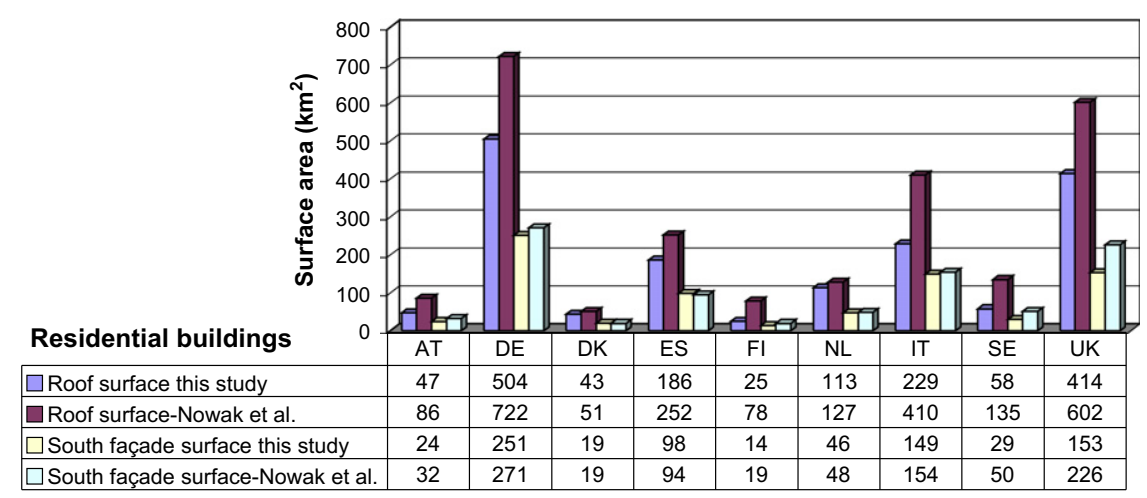

Fig. 9. Comparison BIPV area potential residential buildings this study versus Nowak et al. (2002).

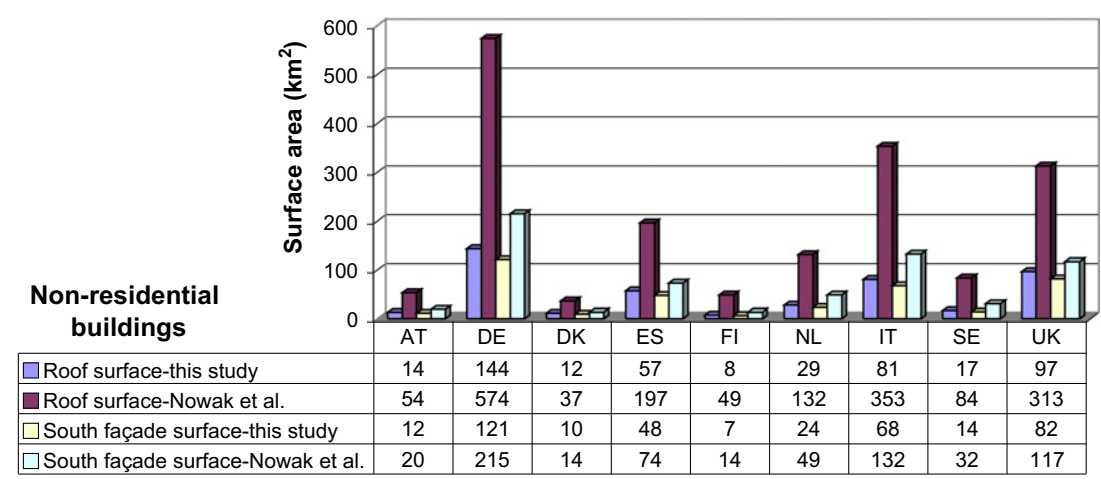

Fig. 10. Comparison BIPV area potential non-residential buildings this study versus Nowak et al. (2002).

2022, 8 years ahead of our initial scenario. Note that not all panels will be used for BIPV but also for (very) large scale PV systems in fields.

The projected increased annual production affects the technical BIPV generation potential since it increases the weighted average efficiency in the period 2005-2030 from $17.9 \%$ to $18.3 \%$ due to the installation of more than $50 \%$ of the PV panels between 2025 and 2030. In this scenario the maximum annual electricity generation from BIPV would increase from $840 \mathrm{TWh}$ to $859 \mathrm{TWh}$, a $2.3 \%$ increase.

\subsection{Comparison of results with previous studies}

In this section we compare our results to previous studies. A much-cited study is an IEA photovoltaic power systems programme BIPV report from Nowak et al. (2002). Fig. 9 shows the differences between both studies for the estimated roof and façade areas in residential buildings for those countries that are included in both studies.

The largest differences are found in the potential roof estimates. This is partly explained as Nowak et al. (2002) propose a statistically typical building in Central Western Europe without accounting for country specific factors, such as the height of buildings. It is also unclear how Nowak et al. (2002) translated the available area per capita towards roof surface without an estimate of ground floor area per habitant. For façades the differences are smaller, with the exception of Sweden and the UK. The latter has a very high percentage $(81 \%)$ single family dwellings and $16 \%$ low rise multi family which leaves only $3 \%$ for high rise dwellings, one of the lowest in Europe. This makes it likely that a UK building differs from a European statistical building. The other country with a large difference is Sweden $(-42 \%$ in our study compared to Nowak et al. (2002) for façades). This difference cannot be explained by the height of the dwellings since Sweden has a more average distribution over the three categories.

Fig. 10 shows the same comparison for non-residential buildings. Because we assumed a different relation between the residential and non-residential sector compared to the Nowak study our analysis results in lower roof potentials. The difference with Nowak et al. (2002) is especially large for this sector as Nowak assumes a $50 \%$ share for the non-residential sector in Europe, while we assume only $30 \%$ derived from Poel (2007).

\subsubsection{Other relevant studies}

There are other methods using more refined techniques for example remote sensing combined with laser scanning. They are usually only suitable for determination of roof areas, however laser scanning (Jochem et al., 2011) has recently been reported to enhance accuracy of façade area determination. These studies do not yet provide data suitable to determine the potential at an European level. 


\section{Conclusions}

Our study shows that in the EU there is a large BIPV potential, equal to $951 \mathrm{GWp}$, providing a considerable share of future electricity use. It can deliver $840 \mathrm{TWh}$ annually, which equals more than $22 \%$ of the expected European electricity demand by 2030 . We developed a method that relies on solid statistical information and extensive European solar radiation research. We had to make assumptions to translate the statistical information into a realistic technical potential for most of the $27 \mathrm{EU}$ member states. Our estimates are lower than earlier estimates due to a difference in floor area calculations. Sensitivity analysis shows that the most influential assumption on the final results is the usable roof area estimate. Additional research to determine the usable roof area more accurate would improve the results. Statistical knowledge about the height of European buildings and the percentage non-residential buildings in relation to the total building stock would further enhance the reliability of the estimates.

\section{Acknowledgements}

We would like to thank Ecofys for their hospitality during the research for this paper. We gratefully acknowledge financial support from the DGRTD (European Community Sixth Framework Programme) and DGENV of the European Commission as well as of the Dutch and German ministries of Environment (VROM and BMU) within the SERPEC-CC (Sectoral Emission Reduction Potentials and Economic Costs for Climate Change) project under Contract No. 044109.

\section{References}

Capros, P., 2007. The PRIMES Energy System Model, Summary Description. NTUA. <http://www.e3mlab.ntua.gr/manuals/PRIMsd. pdf $>$ (accessed 10.06.11).

Clavadetscher, L., Nordmann, T., 2007. Cost and Performance Trends in Grid-Connected Photovoltaic Systems and Case Studies, Report IEA PVPS T2-06:2007. <http://www.iea-pvps-task2.org/public/download/ T2_Cost_and_Performance.pdf $>$ (accessed 25.06.11).

de Keizer, A.C., ter Horst, E., Molenbroek, E.C., van Sark, W.G.J.H.M., 2007. Evaluating 5-years performance monitoring of $1 \mathrm{MW}$ building integrated PV project in Nieuwland, Amersfoort, The Netherlands. In: Willeke, G., Ossenbrink, H., Helm, P. (Eds.), Proceedings of the 22nd European Photovoltaic Solar Energy Conference, WIP-Renewable Energies, Munich, Germany, pp. 29602965.

Defaix, P.R., 2009. The Potential for Solar Electricity Production in the EU-27, MSc. thesis. Sustainable Development: Energy and Resources, Utrecht University, June 2009. <http://www.chem.uu.nl/ nws/www/publica/Publicaties2009/NWS-S-2009-12.pdf $>$ (accessed 31.01.12).

Dimmler, B., Wächter, R., 2007. Manufacturing and application of CIS solar modules. Thin Solid Films 515 (15), 5973-5978 (31 May).

Drews, A., de Keizer, A.C., Beyer, H.G., Lorenz, E., Betcke, J., van Sark, W.G.J.H.M., Heydenreich, W., Wiemken, E., Stettler, S., Toggweiler, P., Bofinger, S., Schneider, M., Heilscher, G., Heinemann, D., 2007. Monitoring and remote failure detection of grid-connected PV systems based on satellite observations. Solar Energy 81, 548-564.
Eiffert, P., 2003. Non-Technical Barriers to the Commercialization of PV Power Systems in the Built Environment, Technical Report NREL/ TP-550-31976, January 2003.

EPIA Publications, 2011. Global market outlook for photovoltaics until 2015. $<$ http://www.epia.org/publications/archives/archives-publications. html $>$ (accessed 25.06.12).

EurObserver PV Barometer, 2011. Systèmes solaires, le journal du photovoltaïque. $<\mathrm{http}: / /$ www.eurobserv-er.org/pdf/baro202.asp $>$ (accessed 25.06.12).

Eurostat, 2010. <http://epp.eurostat.ec.europa.eu/portal/page/portal/ eurostat/home/> (accessed 10.06.11).

Grabmüllerova, D., Eriksson, B.J., 2005. Housing Statistics in the European Union 2004, National Board of Housing, Building and Planning, Sweden and Ministry for Regional Development of the Czech Republic. $<$ http://www.boverket.se/Om-Boverket/Webbokhandel/Publikationer/2005/Housing-Statistics-in-the-European-Union-2004-/> (accessed 10.06.11).

IEA PVPS Task 2 Database. <http://www.iea-pvps-task2.org/database/ index.htm $>$ (accessed 10.06.11).

Jochem, A., Höfle, B., Rutzinger, M., 2011. Extraction of vertical walls from mobile laser scanning data for solar potential assessment. Remote Sensing 3, 650-667.

Nowak, S., 2006. Trends in Photovoltaic Applications, Survey Report of Selected IEA Countries Between 1992 and 2005, Report IEA-PVPS T1-15, August 2006.

Nowak, S., Gutschner, M., Ruoss, D., Togweiler, P., Schoen, T., 2002. Potential for Building Integrated Photovoltaics, Report IEA-PVPS T7-4.

Phylipsen, G.J.M., Alsema, E.A., 1995. Environmental Life-Cycle Assessment of Multicrystalline Silicon Solar Cell Modules, A Study by Commission of NOVEM, September 1995. Department of Science, Technology and Society, Utrecht University.

Poel, B., 2007. EPA-NR, Energy Performance Assessment for Existing Non Residential buildings, EBM-consult Report Number: 070394, August 28, 2007. <http://www.epa-nr.org/files/Overview $\% 20$ of $\% 20$ Results.pdf $>$ (accessed 10.06.11).

PV-TRAC, 2005. A Vision for Photovoltaic Technology, Report by the Photovoltaic Technology Research Advisory Counsil (PV-TRAC), European Commission.

Reich, N.H., Mueller, B., Armbruster, A., van Sark, W.G.J.H.M., Kiefer, K., Reise, Ch., 2012. Performance ratio revisited: are $P R>90 \%$ realistic? Progress Photovolt, in press.

SEII, 2010. Solar Europe Industry Initiative Implementation Plan 20102012, May 2010. <http://ec.europa.eu/energy/technology/initiatives/ $\mathrm{doc} / \mathrm{pv}$ implementation_plan_final.pdf $>$ (accessed 10.06.11).

Sinke et al., 2007. A Strategic Research Agenda for PV Solar Energy Technology, Working group 3 "Science, Technology and Applications" of the EU PV Technology Platform. <http://www.eupvplatform.org/fileadmin/Documents/PVPT_SRA_Complete_070604.pdf $>$ (accessed 10.06.11).

Smeds, J., Wall, M., Hastings, R., 2001. Regional Reference Buildings, Working Document Subtask B: Reference Appartment and Reference Row House, IEA SHC Task 28, ECBCS Annex 38, Energy and Building Design, Department of Construction and Architecture, Lund University, Sweden.

Š́ri, M., Huld, T.A., Dunlop, E.D., Ossenbrink, H.A., 2007. Potential of solar electricity generation in the European Union member states and candidate countries. Solar Energy 81 (10), 1295-1305.

Teske, S., Masson, G., 2011. Solar Generation VI, Greenpeace/EPIA. $<$ http://www.epia.org/publications/photovoltaic-publications-globalmarket-outlook.html $>$ (accessed 31.01.12).

UNECE, 2006. Bulletin of Housing Statistics for Europe and North America 2006, United Nations Economic Commission for Europe. <http:// live.unece.org/hlm/prgm/hsstat/bulletin_06.html $>$ (accessed 10.06.11).

Westerhuis, R., Verhoef, L., Van Sark, W., 2008. Monitoring en lessen PV-Projecten Amersfoort en HAL-gebied, April 21, 2008. Report Number UU: NWS-E-2008-18 (in Dutch). < http://igitur-archive.library.uu.nl/chem/2009-0306-202604/NWS-E-2008-18.pdf> (accessed 10.06.11). 
Wolfsegger, C., Stierstorfer, J., Teske, S., Cameron, M., 2007. Solar Generation IV, Greenpeace/EPIA. < http://www.greenpeace.org/international/press/reports/solar-generation-iv $>$ (accessed 10.06.11).
Wolfsegger, C., Fraile, D., Teske, S., Latour, M., 2008. Solar Generation V, Greenpeace/EPIA. <http://www.greenpeace.org/international/ press/reports/solar-generation-v-2008> (accessed 10.06.11). 